\title{
33 anos de lume, passando por Ilinx
}

Enviado em: 16/12/2018

Aceito em: 10/01/2019

[...] só posso alcançar a despersonalidade da mudez se eu antes tiver construído toda uma voz [...]. É exatamente através do malogro que se vai pela primeira vez ouvir a própria mudez e a dos outros e das coisas e aceitá-la como a possível linguagem. (LISPECTOR, 1998, p. 132)

Estamos no fim do ano de 2018. O Lume já completou 33 anos de existência! Neste período houve a gestação do trabalho com o corpo do ator no Brasil, com e no Lume, a partir de hipóteses e repertório coligidos por Luís Otávio Burnier e experimentados inicialmente por Carlos Simioni, e pouco depois por Ricardo Puccetti. Foi a busca de uma linguagem. Os dois ou três anos iniciais foram de algo como "a despersonalização da mudez" da qual fala Clarice Lispector, já que havia alguns pressupostos, mas além disto uma ao mesmo tempo frenética e paciente busca de expressão - muda - do corpo pessoal, com a finalidade de atingir aspectos gerais, universais. Nos dez anos iniciais do Lume houve a criação de um vocabulário de ações físicas, uma reflexão sobre o cômico, sobre a contribuição e valorização do cotidiano, o caminho para uma dança pessoal que, com ou sem conhecimento do caminho inverso que vinha sendo feito, por exemplo, por Pina Bausch, estava sendo feito pelo Lume: o caminho do apagamento dos limites entre dança e teatro. Não creio que seja excessivo reconhecer que Luís Otávio Burnier, o fundador do Lume, fez para o teatro, no Brasil, para o Brasil e para fora dele, aquilo que um Meyerhold, que um Stanislavski, que um Grotowski, Eugenio Barba fizeram para o teatro em suas terras, projetando-se para o mundo. Costumamos, nós, brasileiros, valorizar muito o que vem de fora. Eu, uma típica brasileira chamada SFS, reconheço em Luís Otávio um valor paralelo ao dos grandes teorizadores do teatro. Aliás, trabalho realizado por ele em apenas dez anos, infelizmente - e felizmente. Porque foi uma vida breve. E parte fundamental deste trabalho consistiu na formação de um grupo de atores. São eles, além de Carlos Simioni e Ricardo Puccetti, já mencionados, Renato Ferracini, Jesser Sebastião de Souza, Ana Cristina Colla, Raquel Scotti Hirson e Naomi Silman. Só sete atores.

Estes aprenderam e desenvolveram um sistema de preparação do corpo extra-cotidiano, a partir de treinamentos cotidianos, assim como firmaram o entendimento de que em país que dificilmente prevê a necessidade da arte como alimento cultural e de equilíbrio humano e social, o desenvolvimento continuado desta arte dependeria de solidariedade, generosidade, extrema organização e muita obstinação. Diferentemente do que se vê habitualmente em grupos, a saber a invisibilização dos competidores (termo usado por Axel Honneth), ou sua desqualificação, o Lume (entendo o grupo todo e cada um do grupo) acolhe atores e grupos que precisam de formação, empresta material para espetáculos,

\footnotetext{
${ }^{1}$ A favor da manutenção e valorização do Ministério de Ciência, Tecnologia e Inovação. A favor do retorno à normalidade democrática. Possui graduação em Letras pela Universidade de São Paulo (1965), mestrado em Letras pela USP (1967), doutorado em Letras pela USP (1972) e Livre-docência em Letras pela UNICAMP. Atualmente é professora titular e professora colaboradora da Universidade Estadual de Campinas, foi coordenadora do Núcleo Interdisciplinar de Pesquisas Teatrais - LUME por treze anos (até sua aposentadoria compulsória).
} 
sempre com cuidado para a preservação dos mesmos. Trata-se de um comportamento agregador, completamente o oposto do que é predito e anunciado para nossos tempos pós-modernos, para a concepção de perda da experiência, segundo Walter Benjamin. Com relação ao teatro pós-dramático, posso considerar que o preparo do corpo de ator e a teorização da prática, iniciada por Burnier e continuada pelo grupo, foram as condições para a produção exatamente do que caracteriza o teatro pós-dramático: aquele que não se escuda em um texto dramatúrgico, criando sua própria dramaturgia, advinda da apreensão da expressão do corpo, em busca da organicidade.

O Lume não é o único grupo de pesquisas teatrais que se manteve unido, vivo, criativo. Há exemplos pelo mundo e no Brasil. Mas não são muitos os casos. E é sempre um desafio. No caso Lume o conjunto dos atores foi crescendo para a autonomia. Isto levou o grupo a empreender espetáculos solo. Segundo Hans-Thies Lehmann, uma das características dos teatros de grupo é a sua dissolução a partir de um tempo. A alternativa à dissolução do grupo, considera ele, é a sua segmentação, especializando-se na apresentação de espetáculos solo. Porque como cada ser humano, o grupo tem necessidade de movimentos diferentes, sempre em busca de desautomatização, de quebra de engessamentos, da busca do novo. Para tanto um grupo, como um indivíduo, precisa de dois movimentos fundamentais: um para dentro de si, centrípeto; e outro para fora de si, porém no grupo, dentro dele e para a sua vivificação. É um movimento centrífugo, sem perder de vista a unidade do grupo e não o seu estilhaçamento. Estes dois movimentos tornam mais verdadeira e eficaz a busca da organicidade. Os dois investimentos, para dentro e para fora, correspondem à sístole e à diástole. $O$ funcionamento depende de uma oxigenação, do novo, da renovação. Se não houver medo, pode-se saber que ambos são necessários para compor a economia e força de um grupo - sendo, no caso, o Lume Teatro.

O desenvolvimento das pesquisas solo levou a que houvesse um investimento consistente na mímesis corpórea, com contribuições pessoais relevantes. Mas não só, porque tanto a dança pessoal, como a expressão do cômico foram desenvolvidas paralelamente principalmente por Carlos Simioni e Ricardo Puccetti. E também por Naomi Silman Cada um desenvolveu uma ou mais das características iniciais do trabalho, por exemplo, de mímesis corpórea, de forma a acrescentar conhecimento especial, sem perder, por isto, a capacidade de integração no grupo. Falar hoje sobre a contribuição de cada um seria extenso. Ela vem existindo, colorindo com formas, vozes, ocupação do espaço, expressividade dos corpos. E com a formação de outros atores, tanto de seu trabalho de corpo, como de teorizações, inclusive porque três dos atores concluíram sua formação acadêmica, doutores de prestígio. E mais um fez o seu mestrado, teorizando sua prodigiosa prática de clown.

A seriedade e cuidado em cada ação, cada espetáculo e cada publicação aproveitou também a interdisciplinaridade, que contribuiu para a formulação de conceitos, evolução de teorias, reflexões capazes de ajudar na verbalização da prática. Houve recurso à semiótica, à antropologia, à filosofia, a longínquos elementos de teoria literária, à história, e à história da cultura e do teatro. Hoje a interdisciplinaridade tem prestígio. Mas não foi sempre assim. E homenageio a coragem, a audácia de Luís Otávio, que investiu no novo, no desconhecido, apostando em conhecimentos, sim, mas também em muitas intuições, assim como apostou no grupo de atores que formou.

Hoje a Unicamp deve estar orgulhosa do Núcleo Interdisciplinar de Pesquisas Teatrais, o Lume Teatro, de sua produção e de seus produtos. E deve estar orgulhosa de ser a única universidade, no Brasil, que mesmo temendo, apoiou o grupo, mesmo levando tempo 
para a regularização da situação do grupo, o tem, como exemplo de trabalho intenso, de grande valor e altamente aglutinador para as artes cênicas no Brasil.

Para chamar a atenção sobre a dificuldade da verbalização da prática, recorrerei a Clarice Lispector:

Eu tenho à medida que designo - e este é o esplendor de se ter uma linguagem. Mas eu tenho mais à medida que não consigo designar. A realidade é a matéria-prima, a linguagem é o modo como vou buscá-la e como não acho. Mas é do buscar e não achar que nasce o que eu não conhecia, e que instantaneamente reconheço. A linguagem é meu esforço humano e por destino volto com as mãos vazias. Mas - volto com o indizível. O indizível só me poderá ser dado através do fracasso de minha linguagem. Só quando falha a construção, é que obtenho o que ela não conseguiu. (LICPECTOR, 1998, p. 132).

Por que recorro a Clarice Lispector? Porque ela verbaliza bem e belamente aquilo que deveria ser compreendido quando se pensa em pesquisa: não há tempo verdadeiramente definido e restrito para a pesquisa. Ela é tão difícil porque tem um forte aspecto apenas suspeitado, cujos avanços só são possíveis passando por decepções. Não, não se trata de falta de referências, de repertório, de conhecimento. É no salto de um velho para um novo conhecimento que a parcela de tempo em que o corpo que se move paira no ar - é aí, no vão, no vazio, no temor, no mutismo - que surge de repente o novo corpo, a voz diferenciada, o conceito insuspeito e bastante ou sutilmente revolucionário.

\section{Referências}

LISPECTOR, Clarice. A Paixão Segundo G.H. CoI. Arquivos. Florianópolis: Ed. da UFSC, 1988. 